\title{
PENAMBAHAN KAPASITAS BANDAR UDARA MARINDA KABUPATEN RAJA AMPAT
}

\author{
Sukamto, Slamet Widodo \\ Program Studi Teknik Sipil Universitas Muhammadiyah Sorong \\ Jl Pendidikan No 27 Kota Sorong
}

\begin{abstract}
Abstrak
Kabupaten Raja Ampat merupakan salah satu daerah yang banyak menyajikan titik titik wisata bahari yang sangat indah, tiap hari banyak sekali wisatawan baik domistik maupun luar negeri yang berkunjung. Sebagai daerah kepulauan, kabupaten ini hanya bias ditempuh dengan jalur laut dari Kota Sorong dengan lama perjalanan menuju ibukota kabupaten yaitu 2 jam menggunakan kapal cepat. Moda transportasi udara menuju Waisai, ibukota Kabupaten Raja Ampat hanya dapat dengan menggunakan pesawat perintis karena panjang landasan baru mencapai 800 meter. Untuk memperlancar transportasi udara dengan kapasitas penumpang yang lebih banyak maka perlu dilaksanakan penambahan kapasitas Bandar Udara Marinda Kabupaten Raja Ampat dengan harapan pesawat terbang Jenis ATR sudah bisa masuk mendarat dan semakin banyak penumpang khususnya wisatawan yang bisa diangkut menggunakan jalur udara. Kementerian Perhubungan Kantor Unit Penyelenggara Bandara Udara Kelas I Bandar Udara Domine Eduard Osok selaku PPK melaksanakan Perpanjangan Runway (90 m x 30 m) diujung Threshold 18 sebagai pengganti Runway (90 m x $30 \mathrm{~m}$ ) diujung threshold 36 untuk penambahan resa sampai dengan Asphalt Hotmix. Untuk melaksanakan pekerjaan tersebut material didatangkan dari luar Raja Ampat. Pekerjaan Perpanjangan Runway tersebut selesai dikerjakan selama 6 bulan oleh penyedia jasa Pt. Karya Utama Persada (kontraktor) dan Cv. Mahbass Yakota Konsultan (konsultan pengawas). Penyelesaian paket pekerjaan ini diharapkan dapat memudahkan transportasi udara menuju fasilitas - fasilitas pemerintahan maupun swasta di Kabupaten Raja Ampat sehingga pertumbuhan ekonomi masyarakat akan meningkat.
\end{abstract}

Kata kunci: penambahan kapasitas, Bandara Marinda, Raja Ampat.

\section{Latar Belakang}

Kabupaten Raja Ampat merupakan salah satu daerah yang banyak menyajikan titik titik wisata bahari yang sangat indah, tiap hari banyak sekali wisatawan baik domistik maupun luar negeri yang berkunjung.

Secara topografi Kabupaten Raja Ampat sangat bervariasi mulai dataran rendah dan berawa. Wilayah Kabupaten Raja Ampat hampir 60 persen berupa daerah pegunungan dengan lereng-lereng yang curam. Dua puluh persen topografi Kabupaten Raja Ampat berupa dataran rendah dan sebagian berawa yang menyebar di bagian selatan sampai ke barat. Bandar Udara Marinda terletak pada Distrik Saonek, Kabupaten Raja Ampat, Provinsi Raja Ampat.

Sebagai daerah kepulauan, kabupaten ini hanya bisa ditempuh dengan jalur laut dari Kota Sorong dengan lama perjalanan menuju ibukota kabupaten yaitu 2 jam

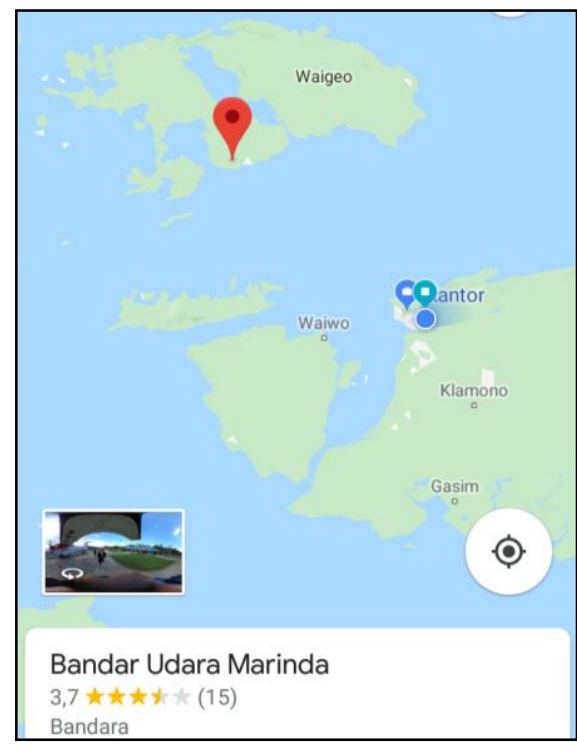
menggunakan kapal cepat. Alternatif yang lain untuk mengakses ibukota Kabupaten Raja 
Ampat adalah dengan tarsnportasi udara dengan transit dulu di Bandara Dominique Edward Osok (DEO) Kota Sorong untuk selanjutnya ganti pesawat menuju Bandara Marinda Waisai ibukota Kabupaten Raja Ampat. Bandara DEO Kota Sorong sebagai bandara transit menuju Kabupaten Raja Ampat yang terletak di tengah kota mempunyai masalah kebisingan dimana tingkat kebisingan di Bandara DEO Sorong terutama di lokasi pengukuran (A1) Sekitar landas pacu bagian barat (75,8dBA), dan (A3) Landas Pacu Bagian Timur (84,7 dBA) di atas ambang baku mutu (55 dBA). Dan (A2) Area terminal Penumpang (75,9 dBA) tingkat kebisingannya diatas ambang baku mutu ( $60 \mathrm{dBA}$ ) mengacu pada ketentuan Menteri Negara Lingkungan Hidup Nomor KEP.48/MENLH/11/1996 (Rachman dan Pristianto, 2018). Belajar dari kondisi Bandara DEO Kota Sorong dan dengan semakin meningkatnya pengguna moda transportasi udara menuju Kabupaten Raja Ampat, maka perlu dilaksanakan penambahan kapasitas Bandar Udara Marinda Kabupaten Raja Ampat dengan harapan pesawat terbang Jenis ATR sudah bisa masuk mendarat.

Proyek penambahan kapasitas bandara ini merupakan proyek pelaksanaan perpanjangan runway pada Bandara Marinda - Waisai, pada bagian pelaksanaan perpanjangan runway, yang mana merupakan Program Kementerian Perhubungan pada Perangkat Kantor Unit Penyelenggara Bandar Udara Marinda - Waisai Kabupaten Raja Ampat untuk dapat meningkatkan frekuensi transportasi udara keluar dan masuk wilayah Kabupaten Raja Ampat. Paket ini adalah program penanganan Reguler, dengan dana kegiatan tersebut berasal dari dana APBN Tahun Anggaran 2017. Kegiatan ini ditangani langsung oleh Kementerian perhubungan selaku Kasatker dan Pejabat Pembuat Komitmen, dan dibantu Pengawas Lapangan serta Tim Konsultan Pengawas/Supervisi. Total panjang jalan yang akan dikerjakan 90 Meter dimana kondisi existing adalah urugan pilihan dan tanah biasa, dimana kegiatan ini dikerjakan oleh Pt. Karya Utama Persada (kontraktor) dan Cv. Mahbass Yakota Konsultan (konsultan pengawas).

\section{Masalah dan Tujuan}

Moda transportasi udara menuju Waisai, ibukota Kabupaten Raja Ampat hanya dapat dengan menggunakan pesawat perintis karena panjang landasan baru mencapai 800 meter. Untuk memperlancar transportasi udara dengan kapasitas penumpang yang lebih banyak.

Kondisi Runway datar dengan kondisi existing urugan pilihan dan tanah biasa , dimana sasaran pekerjaan ini ialah untuk meningkatkan kapasitas Bandar Udara Marinda - Waisai Kabupaten Raja Ampat.

\section{Metode Pelaksanaan}

a. Kontraktor melaksanakan pekerjaan konstruksi sesuai Kontrak nomor KU.003/PPKMRD/057/VIII/2017 tanggal 2 Agustus 2017 dengan jangka waktu pekerjaan mulai 2 Agustus s/d 26 Desember 2017.

b. Konsultan melaksanakan supervisi sesuai Kontrak nomor KU.003/PPK-MRD/SPMKPPR/059/VIII/2017 tanggal 2 Agustus 2017 dengan jangka waktu pekerjaan mulai 2 Agustus s/d 30 Desember 2017. 


\section{Pembahasan}

Kegiatan pada paket ini adalah melaksanakan pekerjaan runway bandar udara dengan panjang efektif 90,00meter (rencana design) dengan lebar runway 30,00meter. Lokasi pekerjaan terletak pada Bandar Udara Marinda Kabupaten Raja Ampat, Provinsi Papua barat, secara geografis terletak pada koordinat di bawah ini :

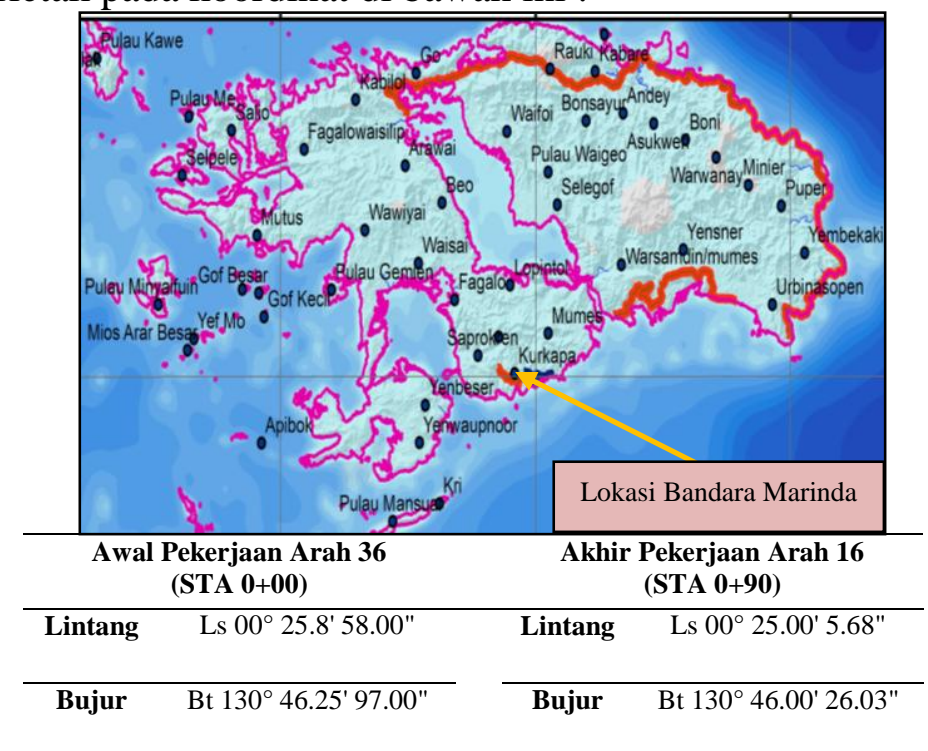

Gambar 2. Detail Lokasi Studi

Di bawah ini adalah kondisi eksisting lokasi studi, seperti terlihat pada gambar 3 .

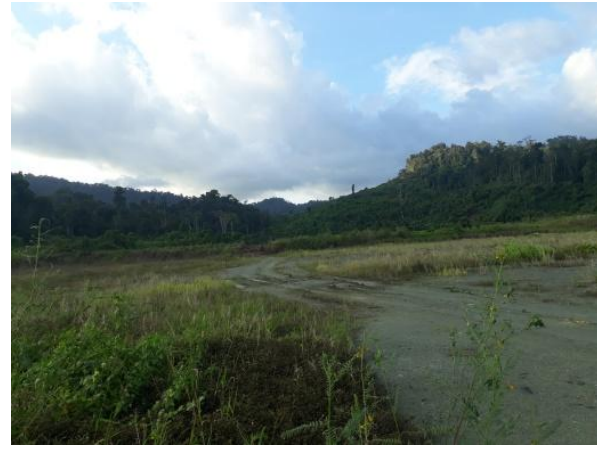

STA. $00+000$

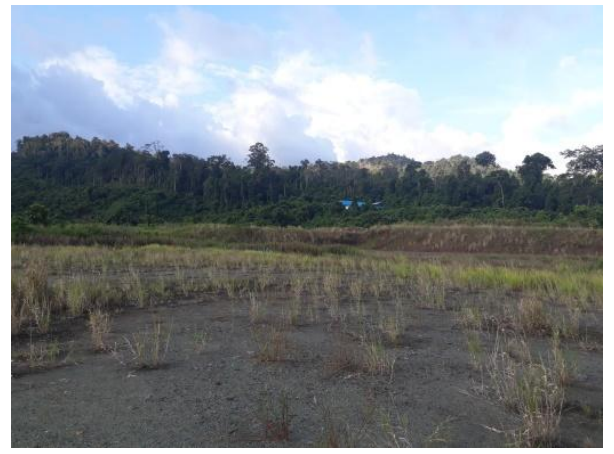

STA. 00+090

Gambar 3. Kondisi Eksisting (0\%) Bandara Marinda Kabupaten Raja Amapat

Tabel 1. Tahapan periode konstruksi

\begin{tabular}{lc}
\hline \multicolumn{1}{c}{ Kegiatan } & Rencana Waktu \\
\hline Awal memulai Mobilisasi Kontraktor + Personil & 02 Agusstus 2017 \\
Akhir Mobilisasi sampai dengan akhir masa layanan Konsultan Supervisi & 30 Agustus 2017 \\
Mobilisasi Personil Konsultan Pengawas ( tiba di lapangan ) & 02 Agusstus 2017 \\
Demobilisasi Personil Konsultan Pengawas ( tinggalkan lapangan ) & 30 Agustus 2017 \\
Awal memulai pekerjaan Konstruksi Runway & 30 Agustus 2017 \\
Akhir pekerjaan Konstruksi Runway & 19 Desember 2017 \\
Awal memulai pekerjaan Tanah Penambahan Resa & 15 November 2017 \\
Akhir pekerjaan Tanah Penambahan Resa & 26 Desember 2017 \\
Awal memulai pekerjaan Asphalt & 19 Desember 2017 \\
Akhir pekerjaan Asphalt & 30 Desember 2017 \\
\hline
\end{tabular}


Pada tahap awal pelaksanaan konstruksi, berdasarkan hasil pemantauan visual dan pengukuran serta investigasi bersama direksi teknik, konsultan supervisi dan kontraktor pelaksana maka disepakati pembuatan galian saluran sementara dibagian kiri perpanjangan runway atau bagian tebing, agar air tidak melintas atau menggenangi area pekerjaan sebagaimana terlihat pada gambar 4 di bawah ini.

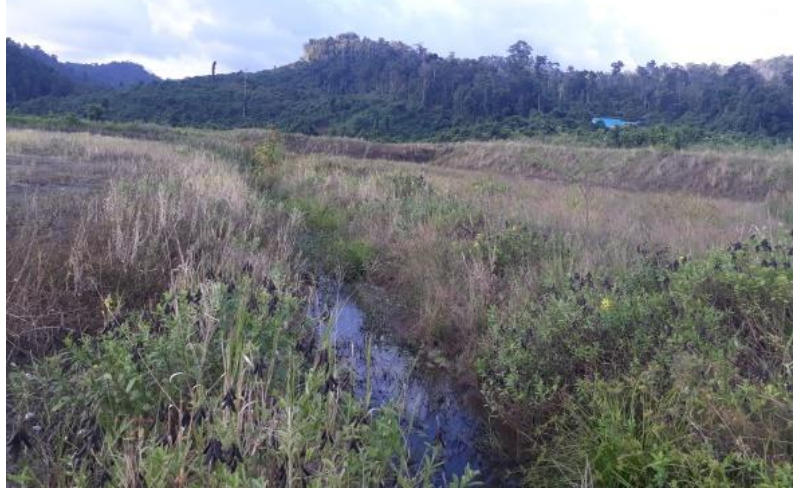

Gambar 4. Permasalahan pada awal tahap konstruksi

Besarnya deviasi per bulan dan identifikasi masalah dapat dilihat pada tabel dengan rincian sebagai berikut :

Tabel 2. Rincian Deviasi per-bulan

\begin{tabular}{|c|c|c|c|c|c|}
\hline No & $\begin{array}{l}\text { Sampai } \\
\text { tanggal }\end{array}$ & Rencana & Realisasi & Deviasi & Identifikasi Masalah \\
\hline 1 & Agt 2017 & $4,440 \%$ & $2,124 \%$ & $-2,316 \%$ & Terlambat mobilisasi \\
\hline 2 & Sept 2017 & $25,980 \%$ & $4,735 \%$ & $-21,245 \%$ & Hasil JMD material urpil belum ada \\
\hline 3 & Okt 2017 & $61,515 \%$ & $8,355 \%$ & $-53,160 \%$ & $\begin{array}{l}\text { Hasil JMD tdk memenuhi syarat, } \\
\text { mencari alternatif quary, sehingga } \\
\text { pekerjaan lain terhambat. }\end{array}$ \\
\hline 4 & Nop 2017 & $84,142 \%$ & $11,579 \%$ & $-72,563 \%$ & $\begin{array}{l}\text { - Material belum ready sesuai jadwal } \\
\text { - Peralatan belum ready sesuai jadwal } \\
\text { - Adanya pemalangan dari masyarakat } \\
\text { adat terhadap quary }\end{array}$ \\
\hline 5 & Des 2017 & $100,00 \%$ & $100,00 \%$ & $0 \%$ & \\
\hline
\end{tabular}

Angka deviasi pada gambar 5 dan tabel 2, menunjukkan bahwa sejak awal pelaksanaan yaitu bulan Agustus 2017 sudah terjadi keterlambatan yaitu terkait mobilisasi alat dan personil. Sedangkan untuk dari bulan September - Nopember lebih pada keterlambatan penyediaan material urugan pilihan yang mana hasil JMD material dari beberapa quary belum memenuhi syarat, sehingga harus berganti-ganti quary. Ditambah lagi bahwa pada bulan Nopember 2017 terjadi permasalahan sosial dengan masyarakat adat yaitu pemalangan quary oleh masyarakat adat. Setelah selesai teknis terkait material dan permasalahan sosial dengan masyarakat, maka di bulan terakhir yaitu Desember 2017 dilakukan peningkatan volume kerja untuk mengejar penyelesaian pekerjaan yang deadline jatuh pada tanggal 30 Desember 2017. 


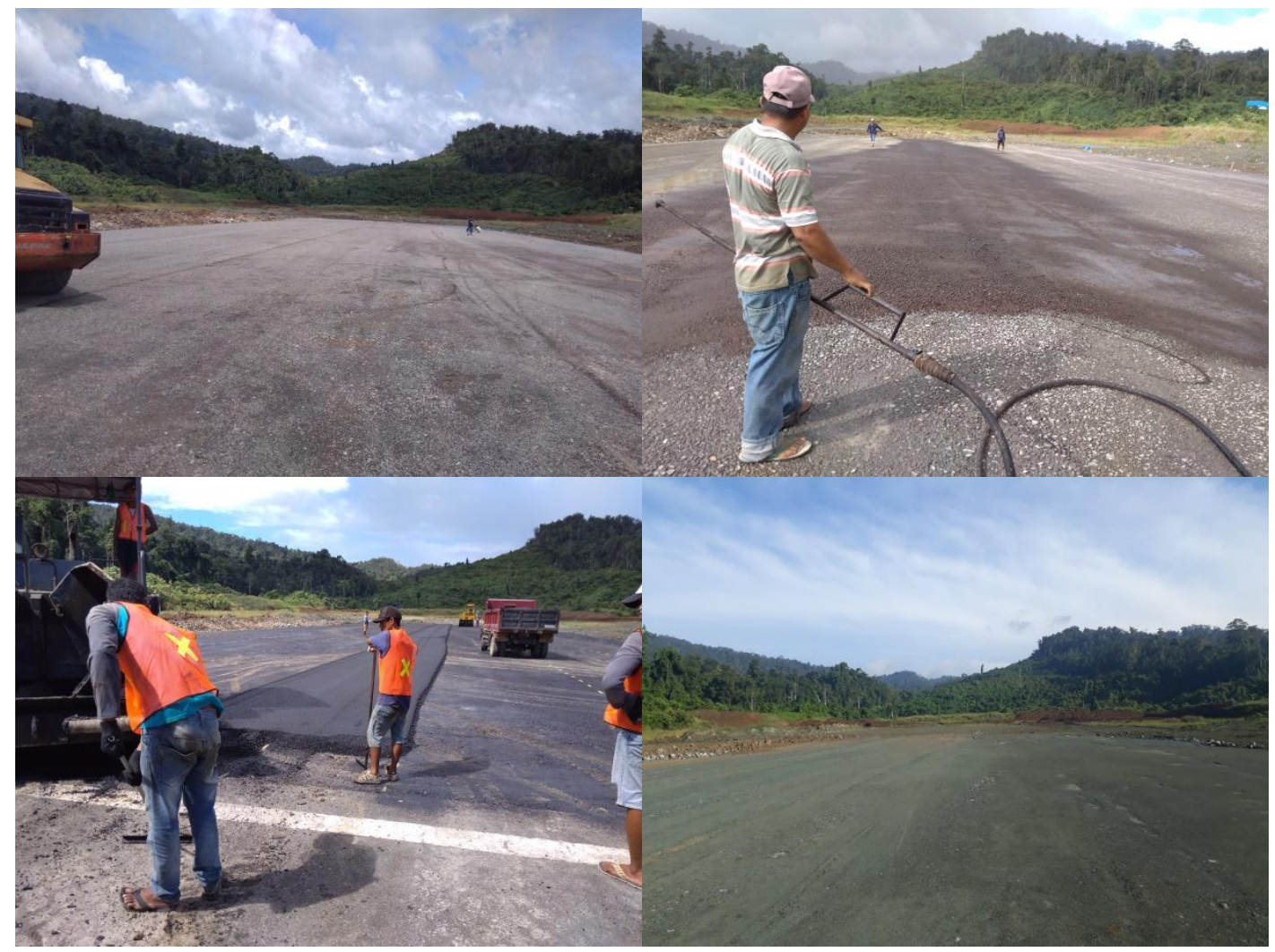

Gambar 5. Dokumentasi Realisasi Pekerjaan (MC 100)

Dengan selesainya paket pekerjaan ini diharapkan frekuensi penerbangan dari dan ke Kabupaten Raja Ampat bisa semakin meningkat dan bisa meningkatkan perekonomian daerah.

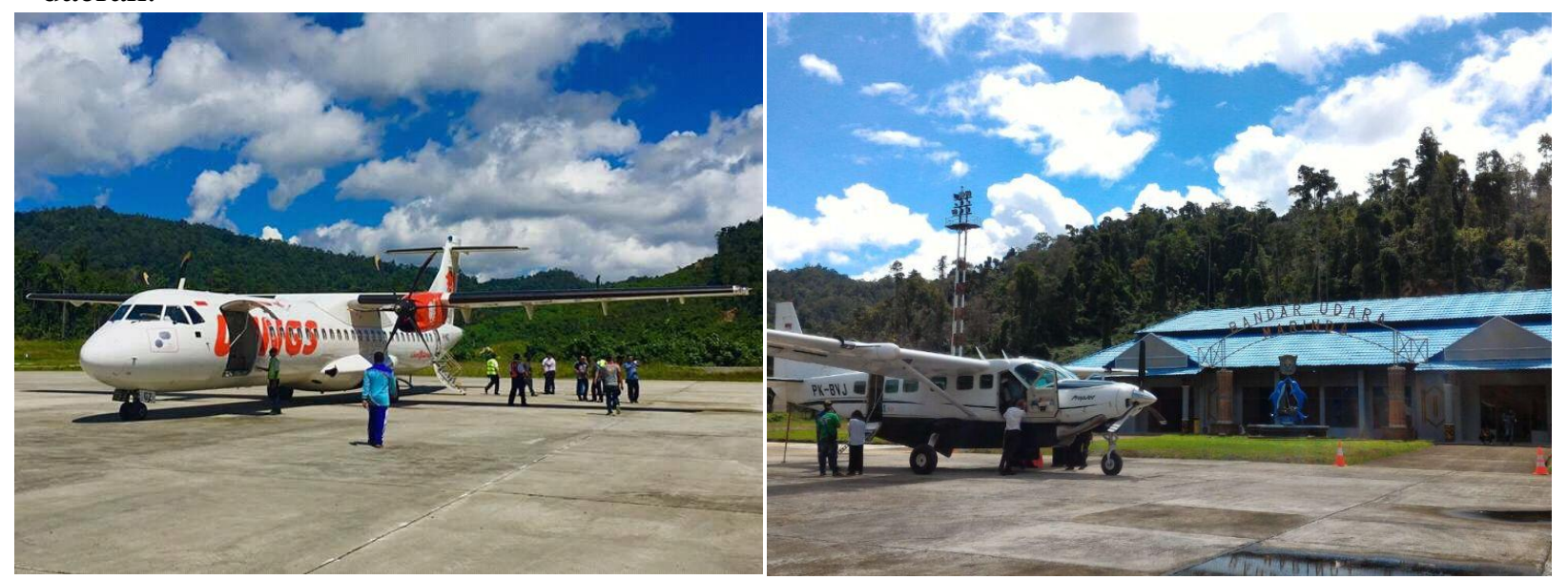

Gambar 6. Dokumentasi aktifitas penerbangan di Bandara Marinda Kabupaten Raja Ampat 


\section{Kesimpulan}

Penambahan kapasitas Bandara Marinda Kabupaten Raja Ampat dilakukan salah satunya dengan pelaksanaan Pekerjaan Perpanjangan Runway (90m X 30m) Di Ujung Threshold 18 sebagai Pengganti 90m X 30m Di Ujung Threshold 36 Untuk Penambahan Resa Sampai Dengan Asphalt Hotmix. Pekerjaan dilaksanakan mulai tanggal 2 Agustus sampai dengan 26 Desember 2017. Progres realisasi pekerjaan tidak berjalan sesuai dengan rencana, sehingga sampai bulan Nopember 2017 terjadi keterlambatan pekerjaan yang disebabkan oleh beberapa hal yang bersifat teknis dan non teknis. Dengan selesainya paket pekerjaan ini diharapkan frekuensi penerbangan dari dan ke Kabupaten Raja Ampat bisa semakin meningkat dan bisa meningkatkan perekonomian daerah.

\section{Daftar Pustaka}

Kementerian Perhubungan (2017). Laporan Kemajuan Pekerjaan Bulan Agustus 2017 Pekerjaan Perpanjangan Runway (90m X 30m) Di Ujung Threshold 18 sebagai Pengganti 90m X 30m Di Ujung Threshold 36 Untuk Penambahan Resa Sampai Dengan Asphalt Hotmix

Kementerian Perhubungan (2017). Laporan Kemajuan Pekerjaan Bulan September 2017 Pekerjaan Perpanjangan Runway (90m X 30m) Di Ujung Threshold 18 sebagai Pengganti 90m X 30m Di Ujung Threshold 36 Untuk Penambahan Resa Sampai Dengan Asphalt Hotmix

Kementerian Perhubungan (2017). Laporan Kemajuan Pekerjaan Bulan Oktober 2017 Pekerjaan Perpanjangan Runway (90m X 30m) Di Ujung Threshold 18 sebagai Pengganti 90m X 30m Di Ujung Threshold 36 Untuk Penambahan Resa Sampai Dengan Asphalt Hotmix

Kementerian Perhubungan (2017). Laporan Kemajuan Pekerjaan Bulan Nopember 2017 Pekerjaan Perpanjangan Runway (90m X 30m) Di Ujung Threshold 18 sebagai Pengganti 90m X 30m Di Ujung Threshold 36 Untuk Penambahan Resa Sampai Dengan Asphalt Hotmix

Kementerian Perhubungan (2017). Laporan Kemajuan Pekerjaan Bulan Desember 2017 Pekerjaan Perpanjangan Runway (90m X 30m) Di Ujung Threshold 18 sebagai Pengganti 90m X 30m Di Ujung Threshold 36 Untuk Penambahan Resa Sampai Dengan Asphalt Hotmix

Rachman, I., \& Pristianto, H. (2018). Analisa Kebisingan Lalu Lintas Udara Di Sekitar Bandar Udara DEO Kota Sorong. 